\title{
Recenzja książki Anny Stawarskiej-Rippel Elementy prywatne i publiczne w procesie cywilnym w świetle prac kodyfikacyjnych w Polsce (1918-1964). Studium historycznoprawne, Katowice 2015, $436 \mathrm{~s}$.
}

\begin{abstract}
Review of Anna Stawarska-Rippel, Elementy prywatne i publiczne w procesie cywilnym w świetle prac kodyfikacyjnych w Polsce (1918-1964). Studium historycznoprawne [The

Private and the Public in Civil Law Procedure and the Codification Process in Poland

(1918-1964): A Study in Legal History], Katowice 2015, 436 p.

The review highlights the key points of Anna Stawarska-Rippel's monograph which presents the process of codification of civil law procedure in Poland from 1918, the year of Poland's independence, until the enactment of a revised Civil Law Code in 1964. The book is based on an impressive collection of primary data and makes full use of the literature in that field. It offers important insights into the codification processes after World War II as well as some probing reflections on the language of the law and the legal discourse. However, the analysis would have been put on firmer ground had the author defined her key terms, i.e. 'private' and 'public elements', and made clear in what way they differed from private and public interest respectively.
\end{abstract}

Key words: civil proceedings, civil procedure code, codification movement, Codification Comission.

Słowa kluczowe: procedura cywilna, kodeks postępowania cywilnego, ruch kodyfikacyjny, Komisja Kodyfikacyjna.

W dotychczasowej literaturze historycznoprawnej nie ma zbyt wielu opracowań poświęconych dziejom procedury cywilnej w Polsce w XX w. Stan ten może budzić zdziwienie wobec istotnej roli, jaką odgrywają normy postępowania cywilnego, i stosunkowo prostego dostępu do zachowanych materiałów źródłowych, zwłaszcza w drugiej połowie XX w. Brakuje przede wszystkim opracowań przekrojowych, ukazujących w szerszej perspektywie historycznoprawnej prace kodyfikacyjne, ewolucję podstawowych zasad postępowania czy skalę wpływu istniejących rozwiązań na proponowane zmiany i za- 
mierzenia kodyfikacyjne. Istniejący stan badań, a także dostrzegalne w nich luki, umiejętnie wskazała w swej monografii dr hab. Anna Stawarska-Rippel, podejmując trud opracowania tych zagadnień. Chciałabym podkreślić, iż doceniam, jak wielkim wyzwaniem była próba ujęcia problematyki nie tylko ze względu na jej złożoność i różnorodność, ale także ze względu na to, że analiza przeprowadzona przez Autorkę dotyczyła odmiennych okresów dziejowych, a zwłaszcza ustrojowych dwudziestowiecznej Polski.

Opracowanie, stanowiące rozprawę habilitacyjną, z pewnością wypełnia istotną lukę badawczą w zakresie dziejów procesu cywilnego w Polsce, choć zaznaczyć należy, że pewne wątpliwości wzbudził we mnie już sam tytuł monografii - Elementy prywatne i publiczne w procesie cywilnym w świetle prac kodyfikacyjnych w Polsce (1918-1964). Studium historycznoprawne. Jak Autorka wspomniała w recenzowanej książce, a także we wcześniejszym artykule, poświęconym elementom publicznym w procesie cywilnym (Elementy publiczne w procesie cywilnym. Ewolucja a rewolucja, ,Studia Iuridica Lublinensia" 2013, t. 19), od drugiej połowy XIX w. na gruncie procedury cywilnej znaczenia nabierała kwestia stosunku interesu publicznego (społecznego) do interesu prywatnego stron procesowych. Trudno się z tym nie zgodzić, w moim jednak przekonaniu nie można postawić znaku równości między ,interesem prywatnym” a „,elementem prywatnym”, podobnie jak nie można postawić znaku równości między ,interesem publicznym” a „elementem publicznym” w procesie cywilnym. Są to pojęcia o innych zakresach.

Proces cywilny, realizowany przed organami sądowymi państwa zgodnie z ustalonymi przez to państwo przepisami, nie może zawierać „elementów prywatnych” w ścisłym tego słowa znaczeniu i jest w swej istocie w całości ,publiczny”, choć ustawodawca w różny sposób stara się wyważyć proporcje między nakazem, stopniem lub sposobami realizacji interesu prywatnego oraz interesu publicznego.

Zauważa to sama Autorka, stwierdzając, że w wypadku procesu cywilnego występuje swoisty dualizm, przejawiający się w tym, że ,proces cywilny mający charakter publiczny i służący ochronie porządku prawnego nakierowany jest na ochronę praw prywatnych" (s. 19). Autorka, choć trzyma się przyjętej w tytule książki terminologii, w istocie analizuje moim zdaniem właśnie relacje między interesem publicznym a interesem prywatnym w procesie, skupiając swą uwagę głównie na „elementach publicznych”. Terminologia przyjęta w tytule książki budzi zatem moje wątpliwości, choć rozumiem ideę Autorki, by na przykładzie ewolucji procesu cywilnego w Polsce (i porównawczo - w Europie) ukazać postępujące od drugiej połowy XIX w. zawężanie sfery prywatnej jednostki na rzecz interesu społecznego/publicznego (s. 9).

Konsekwentnie w konstrukcji książki tej samej terminologii, tj. ,elementy prywatne i publiczne", używa Autorka w tytułach dwóch części, na które podzieliła swą monografię. Część pierwsza (s. 19-250) została poświęcona ,elementom prywatnym i publicznym w postępowaniu spornym przed sądem pierwszej instancji”, część zaś druga (s. 251-382) „elementom prywatnym i publicznym w systemie środków odwoławczych”. W każdej z wymienionych części zachowano podobny układ wewnętrzny: chronologiczno-rzeczowy, ukazujący omawiane przez Autorkę zagadnienia od czasu podjęcia pierwszych prac nad procedurą cywilną w 1917 r. aż do prac nad kodeksem postępowania cywilnego z 1964 r. Analiza konstrukcji wewnętrznej monografii po raz kolejny budzi moje wątpliwości zarówno co do poprawności tytułu całej książki, jak i poszczególnych jej 
części. Co zdaniem Autorki stanowi element „prywatny”, a co „publiczny” przy omawianych przez nią zagadnieniach? Na przykład podrozdziały w rozdziale 2, zatytułowanym „Wstępne założenia i koncepcje zasad polskiego procesu cywilnego (1917-1918)” (s. 35-82): „Ustność czytania czy obszerna podstawa pisemna ustnej rozprawy” (podtytuł 2.4, s. 48 i n.); „Problem zakresu władzy dyskrecjonalnej sędziego na tle rozwiązań w procedurze cywilnej austriackiej, węgierskiej, zuryskiej, berneńskiej oraz niemieckiej i rosyjskiej” (podtytuł 2.5, s. 53 i n.); „Przysięga czy przesłuchanie stron?” (podtytuł 2.6, s. 65 i n.); „Wpływ wyroków karnych na proces cywilny” (podtytuł 2.7, s. 71 i n.); „Udział prokuratora w postępowaniu cywilnym” (podtytuł 2.8, s. 75 i n.)? Co więcej, w treści zacytowanych wyżej tytułów części pracy także nie ma zapowiadanej przez Autorkę w tytule monografii analizy elementów prywatnych i publicznych, a zwłaszcza wskazania, co uważa za „element prywatny”. Z pewnością bezpieczniejsza i budząca mniej wątpliwości byłaby (dokonywana zresztą przez Autorkę w ciekawy sposób, por. s. 255) analiza akcentowania przez uczestników prac kodyfikacyjnych i ustawodawcę potrzeby realizacji interesu prywatnego i publicznego w postępowaniu spornym przed sądem cywilnym.

Być może przedstawionych wyżej wątpliwości terminologicznych nie formułowałabym, gdyby Autorka podjęła próbę określenia/zdefiniowania choćby w ogólny sposób, co rozumie przez pojęcie element prywatny w procesie cywilnym: czy interes prywatny strony, czy zakres swobody stron, autonomii ich woli w postępowaniu (np. widziany poprzez pryzmat zakresu realizacji zasady skargowości, zasady dyspozytywności, zasady kontradyktoryjności), czy także inne elementy? Takiego głębszego odniesienia do treści i znaczenia zasad procesowych (poza cytowaniem poglądów autorów, przytoczonych w monografii) zabrakło moim zdaniem w recenzowanym opracowaniu. Ujęcie problematyki poprzez zakres fundamentalnych zasad procesu cywilnego w ujęciu formułowanym w projektach i postulatach kodyfikacyjnych pozwoliłoby ponadto na bardziej klarowne ujęcie treści poszczególnych rozdziałów książki.

Przyjęty tytuł monografii rodzi bowiem dalsze wątpliwości w aspekcie zawartości poszczególnych części (i rozdziałów) pracy, które koncentrują się w wypadku części pierwszej na analizie prac Komisji Kodyfikacyjnej i poszczególnych autorskich projektów (najobszerniejsza część - rozdział 3 „Postępowanie sporne przed sądem pierwszej instancji w pracach Komisji Kodyfikacyjnej”, s. 83-158), a także (już mniej obszernej) na analizie prac kodyfikacyjnych po II wojnie światowej. W wypadku części drugiej uwaga Autorki skupia się na charakterystyce środków odwoławczych, przedstawieniu systemu niemieckiego, austriackiego, węgierskiego i rosyjskiego (rozdziały 1 i 2), opisaniu wstępnych założeń i koncepcji systemu środków odwoławczych przed powołaniem Komisji Kodyfikacyjnej II RP (rozdział 3, s. 275-292), środków odwoławczych w pracach tejże Komisji (rozdział 4, s. 293-324); środków odwoławczych w kolejnych pracach kodyfikacyjnych (w tym: w rozdziale 5 - nowelizacji kodeksu postępowania cywilnego z 1950 r., s. 325-348; w rozdziale 6 - środków odwoławczych w pracach kodyfikacyjnych w latach 1951-1955, s. 349-360; w rozdziale 7 -środków odwoławczych w pracach Komisji Kodyfikacyjnej i pracach ministerialnych do uchwalenia kodeksu, s. 361-382). Całość monografii poprzedza wstęp (s. 9-15), a zamyka ją syntetyczne zakończenie (s. 383-389). 
Mimo wysuniętych zastrzeżeń monografia dr hab. Anny Stawarskiej-Rippel stanowi cenne opracowanie, wypełniające istniejącą lukę badawczą i wnoszące nowe treści do stanu badań historycznoprawnych. Nadałabym jej jednak inny tytuł, w pełni odpowiadający zawartości i nieumniejszający wartości naukowej opracowania, będącego w istocie rzeczy szerokim, opartym na bardzo gruntownej podstawie w postaci literatury, źródeł drukowanych oraz archiwalnych zarysem dziejów kodyfikacji polskiego procesu cywilnego w XX w. z uwzględnieniem najważniejszych elementów tego procesu - zarówno w postępowaniu przed sądem I instancji, jak i w postępowaniu odwoławczym. Tego rodzaju opracowania, z tak szerokim przekrojem różnorodnych zagadnień, nie było dotychczas $\mathrm{w}$ literaturze historycznoprawnej poświęconej polskiemu procesowi cywilnemu w XX w.

Tej oceny nie umniejsza fakt, iż poszczególne zagadnienia, dotyczące m.in. prac Komisji Kodyfikacyjnej 1919-1939, były już wcześniej opracowane. Anna Stawarska-Rippel wyprofilowała je jednak w autorski sposób, ukazując elementy prac i ich rezultaty etapowe, a całość rozważań oparła na gruntownej podstawie w postaci literatury i drukowanych materiałów źródłowych.

Novum w aktualnej literaturze historycznoprawnej stanowi dokonana przez Autorkę, specjalistkę w zakresie prawa początków Polski Ludowej, próba ukazania prac nowelizacyjnych i kodyfikacyjnych po 1945 r., zwieńczonych uchwaleniem przez Sejm w 1964 r. Kodeksu postępowania cywilnego. Warto odnotować, iż Autorka nie ograniczyła się jedynie do literatury i źródeł drukowanych, lecz sięgnęła także do zespołu akt Ministerstwa Sprawiedliwości w Archiwum Akt Nowych w Warszawie i zrealizowała podstawowy cel, za jaki uznała studia nad dziejami polskiego procesu cywilnego na tle ewolucji tej gałęzi prawa w Europie i świetle ,rewolucji w Polsce po drugiej wojnie światowej, z uwzględnieniem jej wzorców, a także zasięgu w pozostałych państwach demokracji ludowej" (s. 15).

Autorka swobodnie prowadzi swą analizę, ukazując złożone procesy kodyfikacyjne na tle europejskim - zarówno w okresie międzywojennym, jak i w okresie po II wojnie światowej. Za w pełni uzasadnione merytorycznie uważam koncentrowanie się (i w rezultacie szerszą charakterystykę) na pracach Komisji Kodyfikacyjnej Drugiej Rzeczypospolitej, której dorobek stanowił siłą rzeczy punkt odniesienia (pozytywny albo negatywny) do dalszych działań kodyfikatorów. Jako rys charakterystyczny prac nad pierwszym polskim kodeksem postępowania cywilnego podkreślono próbę uwzględnienia w większym zakresie elementów publicznych (termin użyty przez Autorkę), co w zgodzie $\mathrm{z}$ trendami ewolucyjnymi tej gałęzi prawa miało stanowić remedium na niedomagania wymiaru sprawiedliwości (s. 385).

Nie bez znaczenia są także rozważania ogólne ukazujące ewolucję nowożytnego procesu cywilnego w XIX i XX w. (s. 19-28), a także odmienności tzw. socjalistycznego procesu cywilnego (s. 29-34), charakterystykę środków odwoławczych w nowożytnym procesie cywilnym (s. 251-254) oraz w kontekście interesów państwa i jednostki (s. 255-260), jak również dzieje poszczególnych instytucji na ziemiach polskich z zaakcentowaniem wątku prawnoporównawczego (np. kasacja, s. 283 i n.).

W zakresie opracowania dziejów kodyfikacji pierwszej polskiej procedury cywilnej, a także opracowania dziejów dekodyfikacji i rekodyfikacji po II wojnie światowej Autorka wykonała postawione przed sobą zadanie badawcze (por. s. 11 i n.). Udało jej 
się również przedstawić skalę wpływów praw obcych, widoczną zwłaszcza w kontekście recypowania do polskiego porządku prawnego wzorców radzieckich po zmianach politycznych z roku 1948. Analiza przeprowadzona została za pomocą metody historycznej, z wykorzystaniem metody porównawczej. W monografii świadomie zrezygnowano z dogmatycznego opracowania poszczególnych koncepcji oraz instytucji, nadając pracy charakter ściśle historycznoprawny (s. 15). Nie uważam tego za dobre rozwiązanie, bo wzbogacenie rozważań o warstwę teoretycznoprawną pozwoliłoby na przykład uniknąć schematycznego opisu treści kolejnych projektów-referatów, dostrzegalnego nie tylko w wypadku Komisji Kodyfikacyjnej Drugiej Rzeczypospolitej (s. 110-158, 300-316).

Za ważne dla oceny kierunków ewolucji procesu cywilnego w Polsce uważam rozważania poświęcone pracom kodyfikacyjnym prowadzonym po II wojnie światowej. Bardzo interesujące - zwłaszcza wobec zastosowanej szerokiej skali porównawczej są również części opracowania poświęcone udziałowi i roli prokuratora w postępowaniu cywilnym (a zatem wyraźnemu „elementowi publicznemu”). Autorka rozpoczyna swą analizę od przedstawienia zasad obowiązujących u progu niepodległości zgodnie $\mathrm{z}$ „odziedziczonymi” systemami prawa procesowego cywilnego (ukazując także m.in. kierunki zmian dokonujących się w prawie rosyjskim w 1911 r.), poglądów wyrażanych w pierwszym etapie prac kodyfikacyjnych, pogłębia rozważania w odniesieniu do prac prowadzonych w latach $50 . \mathrm{XX}$ w. Interesujące dla badacza dziejów procesu cywilnego są w tym kontekście m.in. przytoczone przez Autorkę uwagi do projektu zgłoszone przez Prokuraturę Generalną (s. 208, 211-212), a także poglądy wyrastające z nauki (s. 219). Udział i rola prokuratora odnotowane zostały także w drugiej części monografii, poświęconej środkom odwoławczym (m.in. s. 279-282). Szkoda, że wątku tego nie wyodrębniono mocniej w obu częściach pracy (np. w osobnych rozdziałach). Służyłoby to problemowemu ujęciu omawianych spraw i umożliwiło odejście od schematu chronologicznego przedstawiania kolejnych projektów, ich zawartości, dyskusji.

Interesującym wątkiem recenzowanej monografii stały się również uwagi o problemach z jednolitym i zrozumiałym dla prawników wszystkich części Drugiej Rzeczypospolitej językiem prawnym i prawniczym, kształtującym się wówczas w szybkim tempie także dzięki intensywnej pracy Komisji Kodyfikacyjnej (s. 105, 108 i n.). Jak bardzo zmieniła się ta terminologia, świadczą m.in. przytoczone przez Autorkę w ślad za projektami członków Komisji określenia „wyrzeczenia sądowe”, „wyrok z omieszkania”. Na tle sporów językowych po raz kolejny uwidocznił się, obecny także podczas innych prac Komisji Kodyfikacyjnej, spór między prawnikami z terenu dawnego Królestwa Kongresowego, broniącymi rozwiązań prawa „francusko-polskiego” a prawnikami z terenów Galicji oraz dawnego zaboru pruskiego. Analizując terminologię, Autorka burzy też stereotyp genezy terminu ,prawda obiektywna”, wykazuje, że używano go w pracach Komisji Kodyfikacyjnej (a zatem nie mógł być użyty po raz pierwszy w ZSRR w 1953 r.). Wątek „terminologiczny” (choć o podłożu ideologicznym) to także skrupulatnie odnotowana przez Autorkę, dokonana w 1950 r. w toku prac nad projektem ustawy „dekodyfikującej” zmiana terminu „rozstrzyganie sporów o prawa prywatne” na rozstrzyganie „spraw cywilnych” (i samych „sporów” na „sprawy”), co nadało projektowanemu prawu nową „klasową treść” (s. 178-179).

Choć Autorka zrezygnowała z analizy teoretycznoprawnej, to w jej pracy znalazły się rozważania ukazujące stan nauki procesu cywilnego po II wojnie światowej i róż- 
nice w poglądach m.in. Michała Waligórskiego oraz Jerzego Jodłowskiego. Krytyczna w zamierzeniu J. Jodłowskiego, autora referatu o stanie nauki polskiej, wypowiedziana w 1950 r. ocena, iż nauka procesu cywilnego wykazuje szczególne zapóźnienie w przyswajaniu metodologii marksistowskiej, wyraża obecnie jakże inną, wysoce pozytywną ocenę środowiska procesualistów polskich po 1945 roku.

Nie bez znaczenia dla stanu badań nad procesem cywilnym uważam również podkreślane przez Autorkę jako istotne w zbliżaniu się rozwiązań w różnych systemach prawnych prowadzenie badań porównawczych i rozwój prawoznawstwa porównawczego. Zjawiska te dostrzegalne były bardzo wyraźnie w warunkach polskich zwłaszcza po I wojnie światowej (ale widoczne także i przy projektowaniu radzieckiego kodeksu postępowania cywilnego z 1923 r.). To jednocześnie podstawowy dla mnie rys charakterystyczny monografii Anny Stawarskiej-Rippel: szerokie ujęcie omawianych zagadnień i ich europejskiego, prawnoporównawczego kontekstu.

Monografia została oparta na bardzo bogatej, skrupulatnie zebranej literaturze przedmiotu (wykaz obejmuje pozycje wyliczone na s. 400-421), źródłach drukowanych (wykaz s. 393-395) oraz aktach normatywnych z XIX i XX stulecia (wykaz s. 395-400). Jak wyżej wspomniano, na podkreślenie zasługuje wykorzystanie źródeł archiwalnych - zespołu akt Ministerstwa Sprawiedliwości - wzbogacających przeprowadzoną przez Autorkę analizę. W obszernym wykazie bibliograficznym, w wymienionych wyżej grupach znalazły się zarówno pozycje polskojęzyczne (co zrozumiałe - w przeważającej mierze), jak i pozycje w języku rosyjskim, niemieckim, francuskim, węgierskim oraz angielskim. Praca napisana została poprawną polszczyzną, czyta się ją z zainteresowaniem. Słowa uznania należą się także Wydawnictwu Uniwersytetu Śląskiego i wyróżniającej pracę starannej korekcie (dostrzeżono nieliczne usterki, np. pominięcie dwukrotnie imienia Władysław w wypadku W.L. Jaworskiego). 